ISSN 0258-7122 (Print), 2408-8293 (Online)

Bangladesh J. Agril. Res. 42(4): 621-629, December 2017

\title{
EFFECT OF FERMENTED TEA EXTRACT IN CONTROLLING BROWN SPOT AND NARROW BROWN SPOT OF RICE
}

\author{
N. Sultana ${ }^{1}$, C. MONDAL ${ }^{2}$, M. M. HOSSAIN ${ }^{3}$ \\ M. A. R. KHOKON ${ }^{4}$ AND M. R. ISLAM ${ }^{5}$
}

\begin{abstract}
Compost tea, Tilt $250 \mathrm{EC}$ and Bavistin $50 \mathrm{WP}$ were evaluated for controlling brown spot and narrow brown spot diseases of rice in the field laboratory of the Department of Plant Pathology, Bangladesh Agricultural University, Mymensingh during the period from July to December, 2011. Significant effect of different treatments was observed on the severity of brown spot and narrow brown spot of rice as compared to control. The results evidently showed the lowest brown spot severity in $\mathrm{T}_{4}$ (Tilt $250 \mathrm{EC}$ applied as foliar spray) which was statistically similar to $\mathrm{T}_{3}$ (Compost tea as soil drenching) while the highest severity was recorded in untreated control plot at booting and ripening stage. But narrow brown spot severity was lowest in $\mathrm{T}_{4}$ (Tilt $250 \mathrm{EC}$ as foliar spray) which was similar to $\mathrm{T}_{5}$ (Tilt $250 \mathrm{EC}$ as soil drenching), $\mathrm{T}_{6}$ (Bavistin $50 \mathrm{WP}$ as foliar spray) and highest severity was found in $\mathrm{T}_{2}$ (Compost tea as foliar spray) which was statistically similar to $\mathrm{T}_{1}$ (control), $\mathrm{T}_{3}$ (Compost tea as soil drenching), $\mathrm{T}_{7}$ (Bavistin $50 \mathrm{WP}$ as soil drenching) at booting stage. But at ripening stage the highest severity was found in $\mathrm{T}_{1}$ (control) and the lowest severity was found in $\mathrm{T}_{4}$ (Tilt $250 \mathrm{EC}$ as foliar spray) which was statistically similar to $\mathrm{T}_{5}$ (Tilt $250 \mathrm{EC}$ as soil drenching). However, soil drenching and foliar application of compost tea performed better as compared to control in reducing the severity of brown spot. But compost tea as foliar spray increased the narrow brown spot disease. Significant effect of the treatments was observed on growth and yield contributing characters except panicle length. Foliar and soil application of Tilt and soil application of compost tea showed better performance in increasing growth and yield contributing characters as compared to all other treatments.
\end{abstract}

Keywords: Compost tea, brown spot, narrow brown spot, rice

\section{Introduction}

Rice (Oryza sativa L.) is one of the staple food crops of world especially in south east asia and at the same time it attains the second position on cereal road map of world after wheat. Approximately $90 \%$ rice is produced and consumed in Asia (Salim et al., 2003). It is the staple food of Bangladesh, but yield of this crop is comparatively lower than that of even neighboring countries. At present the total annual rice production in the country is approximately 34.7097 million metric

${ }^{1}$ Ex-student of Department of Plant Pathology, Bangladesh Agricultural University (BAU), Mymensingh, ${ }^{2}$ Assistant Professor of Agrotechnology Discipline, Khulna University, Khulna, ${ }^{3}$ Ex-Professor of Department of Plant Pathology, BAU, Mymensingh, ${ }^{4 \& 5}$ Professor of Department of Plant Pathology, BAU, Mymensingh, Bangladesh. 
tons and the average yield is around $2.876 \mathrm{mt} \mathrm{ha}^{-1}$ (BBS, 2016) while the world's total production is 497.8 million tons (FAO, 2016).

The rice production is seriously affected by diseases over its entire growth period. Diseases can affect both productivity and grain quality as well (Santos et al., 2009). Out of 31 rice diseases, 10 are considered as major diseases (Miah et al., 1985; Shahjahan et al., 1987). Among the diseases, brown spot (Bipolaris oryzae) and narrow brown spot (Cercospora oryzae) cause substantial loss to rice both in quality and quantity in the present ecosystem in Bangladesh. Rice is suffering from brown spot disease to a great extent and caused Bengal famine in 1943 (Padamanabhan, 1973). Brown spot caused an estimated loss of 4.58-29\% in grain weight and 11.0-37.3\% reduction in germination of rice in Panjab (Bedi et al., 1960). Narrow brown spot cause a great loss both in the storage and field. Besides Cercospora oryzae, the causal agent of narrow brown spot reduced the seed viability of rice (Arunyarat et al., 1981).

The common diseases of rice are being controlled specially by spraying fungicides that cause environmental pollution. The indiscriminate use of chemicals for controlling diseases of crop plants resulted environmental pollution and health hazards. The costly chemicals are being imported from abroad and farmers have to pay a high price. Moreover, huge amount of foreign currency is needed to purchase plant protecting chemicals. As an alternate means of avoiding these limitations, biological agents may be used for combating the diseases with the aim of increasing crop production. The biological control of pathogen offers environmentally safe, durable and cost effective alternatives to chemical compounds (Papavizas and Lumsden, 1980).

Composts are known to suppress plant diseases through a combination of physiochemical and biological characteristics. Physiochemical characteristics i.e. any physical or chemical aspects of composts that reduce disease severity by directly or indirectly affecting the pathogen or host capacity for growth due to the effect of nutrient level, organic matter, moisture, $\mathrm{pH}$, and other factors. Recently, Compost tea has been defined simply as liquid extract from compost material that may contain organic and inorganic soluble nutrients and a large number of organisms including bacteria, fungi, protozoa and nematodes (Rou, 2003). Thus using compost tea instead of solid compost application to the soil may be the best use of technology to improve crop productivity and crop health. Therefore, the present study was undertaken to evaluate the efficacy of compost tea in controlling brown spot and narrow brown spot of rice as compared to other chemicals and also its effect on plant growth, yield and yield contributing characters of rice.

\section{Materials and Methods}

The experiment was conducted at the Field Laboratory, Department of Plant Pathology, Bangladesh Agricultural University (BAU), Mymensingh during the period from 21 August 2011 to 12 December 2011. A high yielding cultivar of 
rice 'BR14' was selected for this study. The experiment was laid out in a Randomized Complete Block Design (RCBD) with three replications. Distances between the blocks and between the plots were $50 \mathrm{~cm}$ and $25 \mathrm{~cm}$, respectively. The size of unit plot was $2 \mathrm{~m} \times 1.5 \mathrm{~m}$. A total of seven treatments were used, viz. $\mathrm{T}_{1}$ (Control no spray), $\mathrm{T}_{2}$ (Compost tea as foliar spray), $\mathrm{T}_{3}$ (Compost tea as soil drenching), $\mathrm{T}_{4}$ (Tilt $250 \mathrm{EC}$ as foliar spray), $\mathrm{T}_{5}$ (Tilt $250 \mathrm{EC}$ as soil drenching), $\mathrm{T}_{6}$ (Bavistin 50 WP as foliar spray) and $\mathrm{T}_{7}$ (Bavistin $50 \mathrm{WP}$ as soil drenching). The land used for seed bed was marshy and no fertilizers were applied. Clean and mature seeds were soaked in tap water for 24 hours and incubated 48 hours for germination before sowing in the seed bed. The germinated seeds were sown uniformly in the seed bed.

\section{Preparation of Compost tea}

Compost tea was obtained by mixing compost with tap water at a ratio of 1:5(w/v) followed by fermentation for one week. It was stirred once in every day and allowed to ferment in the Nethouse, Seed Pathology Centre, BAU, Mymensingh at $25^{\circ} \mathrm{C}$. After 7 days, the solution was filtered through cheese cloth. The prepared compost tea was ready for application with ordinary sprayers.

\section{Application of fertilizer and manures}

The chemical fertilizers were applied in the field as per recommended dose of Bangladesh Rice Research Institute (BRRI). TSP, MoP, Gypsum and Zinc sulphate except urea were applied (all plots) at the time of final land preparation. Urea was applied in equal splits at 15,30 and 45 days after transplanting. Organic amendments with cowdung (10 ton/ha), Neem oil cake (150 kg/ha) and Mustard oil cake $(133 \mathrm{~kg} / \mathrm{ha})$ were also accomplished at the time of final land preparation.

\section{Transplanting of rice seedling in experimental plots}

After preparing the land, 32 days old seedlings of BR 14 were uprooted carefully to avoid root injury. The seedlings were transplanted in the experimental plots using three seedlings/hill. Plant to plant and row to row spacing were $15 \mathrm{~cm}$ and $20 \mathrm{~cm}$, respectively. In case of missing hill necessary gap filling was done at 10 days after transplanting. Weeding was done twice.

\section{Recording of Diseases Severity in the Field}

Data were recorded visually by observing the symptoms at booting and ripening stages. Four leaves from the top of the plant were considered for grading the severity of diseases. Five plants in each plot were randomly selected for recording the disease severity and the selected plants were tagged. The severity of two diseases viz. brown spot and narrow brown spot were recorded (0-9 scale) following Standard Evaluation System for Rice (IRRI, 1980). The grading scale for brown spot of rice was $0=$ No incidence, $1=$ Less than $1 \%$ area affected, $2=$ 
$1-3 \%$ areas affected, $3=4-5 \%$ areas affected, $4=6-10 \%$ areas affected, $5=11-$ $15 \%$ areas affected, $6=16-25 \%$ areas affected, $7=26-50 \%$ areas affected, $8=$ $51-75 \%$ areas affected and $9=76-100 \%$ areas affected. The grading scale for narrow brown spot of rice was $0=$ No incidence, $1=$ Less than $1 \%$ area affected, $3=1-5 \%$ areas affected, $5=5-25 \%$ areas affected, $7=26-50 \%$ areas affected and $9=51-100 \%$ areas affected

\section{Data Collection on growth and yield and Analysis}

The data were collected on the growth and yield parameters of rice. These data were analyzed statistically and the treatment means were compared by Duncan's Multiple Range Test (DMRT).

\section{Results and Discussion}

\section{Severity of Brown spot}

At booting stage highest severity $(6.67 \%)$ was recorded in $\mathrm{T}_{1}$ (control) and lowest severity $\left(2.47 \%\right.$ ) was in $\mathrm{T}_{4}$ (Tilt as foliar spray) which was almost similar to $\mathrm{T}_{3}$ (Compost tea as soil drenching) (Table 1). Similarly, at ripening stage, highest severity $(66 \%)$ was found in $\mathrm{T}_{1}$ (control) and lowest severity (13.87\%) was observed in $\mathrm{T}_{4}$ (Tilt as foliar spray). Lower severity (26.27\%) was recorded in $\mathrm{T}_{3}$ (Compost tea as soil drenching) (Table 1).

Table 1. Effect of compost tea on severity of brown spot in rice at booting stage and ripening stage

\begin{tabular}{l|cc}
\hline \multirow{2}{*}{ Treatments } & \multicolumn{2}{c}{ Disease severity (\%) of brown spot of rice } \\
\cline { 2 - 3 } & Booting stage & Ripening stage \\
\hline $\mathrm{T}_{1}=$ Control & 6.67 & 66.00 \\
$\mathrm{~T}_{2}=$ Compost tea(foliar spray) & 5.67 & 45.00 \\
$\mathrm{~T}_{3}=$ Compost tea (Soil drenching) & 3.00 & 26.27 \\
$\mathrm{~T}_{4}=$ Tilt(Foliar spray) & 2.47 & 13.87 \\
$\mathrm{~T}_{5}=$ Tilt (Soil drenching) & 5.53 & 34.13 \\
$\mathrm{~T}_{6}=$ Bavistin (Foliar spray) & 6.27 & 28.70 \\
$\mathrm{~T}_{7}=$ Bavistin (soil drenching) & 5.87 & 39.60 \\
\hline
\end{tabular}

\section{Severity of Narrow Brown spot}

In booting stage the highest severity $(4.60 \%)$ was found in $\mathrm{T}_{2}$ (Compost tea as soil drenching) and higher severity $(4.53 \%)$ was found in $\mathrm{T}_{1}$ (control) and lowest severity $\left(1.40 \%\right.$ ) was found in $\mathrm{T}_{4}$ (Tilt as foliar spray) (Table 2). Besides, highest severity $(63.37 \%)$ was found in $\mathrm{T}_{1}$ (control) at ripening stage and lowest severity $(16.30 \%)$ in $\mathrm{T}_{4}$ (Tilt as foliar spray) which was almost similar to $\mathrm{T}_{5}$ (Tilt as soil drenching) (Table 2). 
Table 2. Effect of compost tea on severity of narrow brown spot in rice at booting stage and ripening stage

\begin{tabular}{l|c|c}
\hline \multirow{2}{*}{\multicolumn{1}{c|}{ Treatments }} & \multicolumn{2}{c}{$\begin{array}{c}\text { Disease severity (\%) of narrow brown } \\
\text { spot of rice }\end{array}$} \\
\cline { 2 - 3 } & Booting stage & Ripening stage \\
\hline $\mathrm{T}_{1}=$ Control & 4.53 & 63.37 \\
$\mathrm{~T}_{2}=$ Compost tea (foliar spray) & 4.60 & 45.07 \\
$\mathrm{~T}_{3}=$ Compost tea (Soil drenching) & 3.73 & 32.00 \\
$\mathrm{~T}_{4}=$ Tilt(Foliar spray) & 1.40 & 16.30 \\
$\mathrm{~T}_{5}=$ Tilt (Soil drenching) & 2.00 & 16.80 \\
$\mathrm{~T}_{6}=$ Bavistin (Foliar spray) & 2.00 & 24.67 \\
$\mathrm{~T}_{7}=$ Bavistin (soil drenching) & 3.53 & 41.73 \\
\hline
\end{tabular}

\section{Number of tiller and hill}

The highest number of tillers per plant (16.93) was recorded in case of foliar application of Tilt $\left(\mathrm{T}_{4}\right)$ which was statistically similar to $\mathrm{T}_{2}, \mathrm{~T}_{3}$, and $\mathrm{T}_{5}$. The lowest number of tillers (13.93) was found in Bavistin soil drenched $\left(\mathrm{T}_{7}\right)$ plot (Table 3). The maximum number of hills per plot (26.33) was recorded due to foliar application of Compost tea $\left(\mathrm{T}_{2}\right)$, while minimum number of hills (20.33) was found in Bavistin soil drenched $\left(\mathrm{T}_{7}\right)$ plot (Table 3).

Table 3. Effect of compost tea on growth and yield contributing characters in rice cv. BR14

\begin{tabular}{|c|c|c|c|c|c|c|}
\hline Treatments & $\begin{array}{l}\text { No. of } \\
\text { tiller/plant }\end{array}$ & \begin{tabular}{|c|} 
Hill \\
number/ \\
plot
\end{tabular} & $\begin{array}{c}\text { Plant } \\
\text { height }(\mathrm{cm})\end{array}$ & $\begin{array}{c}\text { Panicle } \\
\text { length } \\
(\mathrm{cm})\end{array}$ & $\begin{array}{c}\text { Grain } \\
\text { number/ } \\
\text { ear }\end{array}$ & $\begin{array}{c}\text { Chaffy } \\
\text { grain } \\
\text { number/ear }\end{array}$ \\
\hline $\mathrm{T}_{1}=$ Control & $14.60 \mathrm{~b}$ & $23.00 \mathrm{bc}$ & $92.10 \mathrm{c}$ & 20.00 & $123.89 \mathrm{c}$ & $64.89 \mathrm{a}$ \\
\hline $\begin{aligned} \mathrm{T}_{2}= & \text { Compost } \\
& \text { tea(foliar spray })\end{aligned}$ & $16.27 \mathrm{a}$ & $26.33 \mathrm{a}$ & $100.78 \mathrm{abc}$ & 21.83 & $131.67 \mathrm{c}$ & $46.67 \mathrm{bc}$ \\
\hline $\begin{aligned} \mathrm{T}_{3}= & \text { Compost tea } \\
& \text { (Soil drenching) }\end{aligned}$ & $16.07 \mathrm{a}$ & $23.33 b$ & $102.83 \mathrm{abc}$ & 20.87 & $142.78 \mathrm{ab}$ & $40.22 \mathrm{~d}$ \\
\hline $\mathrm{T}_{4}=\operatorname{Tilt}($ Foliar spray $)$ & $16.93 \mathrm{a}$ & $23.00 \mathrm{bc}$ & $106.72 \mathrm{ab}$ & 21.05 & $151.89 a$ & $34.00 \mathrm{e}$ \\
\hline $\begin{aligned} \mathrm{T}_{5}= & \text { Tilt }(\text { Soil } \\
& \text { drenching) }\end{aligned}$ & $16.67 \mathrm{a}$ & $22.67 b c$ & $111.92 \mathrm{a}$ & 20.89 & $134.11 b c$ & $43.89 \mathrm{~cd}$ \\
\hline $\begin{array}{c}\mathrm{T}_{6}=\underset{\text { spray) }}{\text { Bavistin (Foliar }} \\
\text { spris }\end{array}$ & $14.33 b$ & $24.00 \mathrm{ab}$ & $102.30 \mathrm{abc}$ & 21.14 & $129.44 c$ & $49.67 \mathrm{~b}$ \\
\hline $\begin{array}{c}\mathrm{T}_{7}=\begin{array}{c}\text { Bavistin (soil } \\
\text { drenching) }\end{array} \\
\end{array}$ & $13.93 b$ & $20.33 c$ & $99.27 b c$ & 21.00 & $126.33 \mathrm{c}$ & $50.12 b$ \\
\hline LSD at $5 \%$ & 1.99 & 2.09 & 7.52 & - & 12.91 & 5.39 \\
\hline $\mathrm{CV}(\%)$ & $7.20 \%$ & $5.07 \%$ & $4.14 \%$ & $7.87 \%$ & $5.40 \%$ & $6.43 \%$ \\
\hline Level of sig. & $*$ & $* *$ & $* *$ & NS & $* *$ & ** \\
\hline
\end{tabular}

$*=$ Significant at $5 \%$ level of probability, $* *=$ Significant at $1 \%$ level of probability, NS = Not significant 


\section{Plant height and panicle length}

The highest plant height (111.92) was recorded by soil drenching of Tilt $\left(\mathrm{T}_{5}\right)$ and lowest plant height (92.1) was found in control treatment $\left(T_{1}\right)$ (Table 3). There was no significant variation in case of panicle length and it ranged from 20 to $21.83 \mathrm{~cm}$.

\section{Number of grains and yield}

Maximum number of grains per panicle (151.89) was recorded in case of foliar application of Tilt $\left(\mathrm{T}_{4}\right)$ the minimum number of grains (123.89) was in control treatment $\left(T_{1}\right)$ which was statistically similar to $T_{2}, T_{6}$, and $T_{7}$ (Table 3). On the other hand, maximum number of chaffy grains (64.89) was found in control treatment $\left(\mathrm{T}_{1}\right)$ and minimum number of chaffy grains (34) was recorded in case of foliar application of Tilt $\left(\mathrm{T}_{4}\right)$ (Table 3$)$. The grain yield of rice varied significantly among the treatments. The highest grain weight $(7.67 \mathrm{t} / \mathrm{ha})$ was found in $\mathrm{T}_{4}$ which was followed by $\mathrm{T}_{3}(7.34 \mathrm{t} / \mathrm{ha})$ and the lowest $(6.17 \mathrm{t} / \mathrm{ha})$ was found in $\mathrm{T}_{1}, \mathrm{~T}_{2}, \mathrm{~T}_{6}$ and $\mathrm{T}_{7}$ treatments (Table 4 ).

Table 4. Effect of compost tea on grain yield in rice cv. BR14

\begin{tabular}{l|c}
\hline \multicolumn{1}{c|}{ Treatments } & Grain yield (t/ha) \\
\hline $\mathrm{T}_{1}=$ Control & $6.17 \mathrm{~d}$ \\
$\mathrm{~T}_{2}=$ Compost tea (foliar spray) & $6.17 \mathrm{~d}$ \\
$\mathrm{~T}_{3}=$ Compost tea (Soil drenching) & $7.37 \mathrm{~b}$ \\
$\mathrm{~T}_{4}=$ Tilt (Foliar spray) & $7.67 \mathrm{a}$ \\
$\mathrm{T}_{5}=$ Tilt (Soil drenching) & $6.83 \mathrm{c}$ \\
$\mathrm{T}_{6}=$ Bavistin (Foliar spray) & $6.17 \mathrm{~d}$ \\
$\mathrm{~T}_{7}=$ Bavistin (soil drenching) & $6.17 \mathrm{~d}$ \\
\hline LSD at 5\% & 16.26 \\
CV $(\%)$ & $1.38 \%$ \\
\hline
\end{tabular}

Spraying of Tilt showed lowest severity of brown spot and narrow brown spot disease at both booting stage and ripening stage that was supported by the findings of Percich and Huot (1989). Soil drenching of compost tea reduced brown spot disease because after application it works rapidly at the time of sporulation of fungus and thus inhibit the sporulation process. So fungus cannot cause brown spot disease severely. The results supported by Zinati (2005) who showed use of compost resulted suppression of root rot disease caused by Phytophthora, where mechanism like antibiosis, competition, hyperparasitism and induced resistance worked. Wickramaarachchi et al. (2003) reported disease reduction by applying compost extract. Ryan et al. (2005) reported the use of aerated water extracts or tea from compost to control foliar diseases. Kelley (2004) studied the efficacy of aerated compost tea for plant disease control. Aldahmani (2005) reported that compost-amended substrates offered the potential for management of diseases caused by soil borne as well as foliar plant pathogens. 
Organic manures have been reported to have some positive impact in reducing the incidence and severity of many diseases of some economically important crop plants (Aryantha et al., 2000; Nelson et al., 2002; Shaikh and Ghaffar, 2004; Ben Jenana et al., 2009; Saadi et al., 2010; Pane et al., 2011; Ahmed et al., 2012).

Compost tea enhanced the growth and yield parameters of rice. Foliar and soil application of compost tea and Tilt showed better performance in increasing growth and yield as compared to all other treatments. Goerlach (1996) reported that the application of Tilt reduced diseases and increased grain yield by up to 1400 pound/acre and milling yield by $12 \%$. Compost tea enhanced the grain weight significantly. This result was supported by Ngakou et al. (2012). Merill et al. (1998) reported that organic teas increased vigour and hardness on the plant by providing both micronutrients and the organic chelating agents. The increased yield and protein content were also reported in potato when plants were grown in the soil applied composted animal manure (Srikumar and Ockerman, 1990) and composted plant material added to soil was also observed for increasing yield in sweet potato (Preston, 1990; Floyd et al., 1988). Significant increase in tomato yield was also reported with compost amendment (Cheuk, 2005). Besides, significant yield increase in eggplant was observed as a result of disease suppressiveness and growth promoting effect of compost (Paplomatas, 2005).

\section{Conclusion}

Soil drenching of compost tea might be used as an alternative environment friendly means to control brown spot of rice. Soil and foliar application of compost tea contributed positively towards increasing growth, yield and yield contributing characters of rice. But compost tea as foliar spray enhanced the narrow brown spot disease. Further investigations are required to draw any conclusion on the use of compost tea in controlling narrow brown spot of rice.

\section{References}

Ahmed, S., N. Zaman and S. N. Khan. 2012. Evaluation of manuring practices on root rot disease and agronomic characters of Arachis hypogeae L. African J. Biotechnol, 11(5): 1119-1122.

Aldahmani, D. 2005. Reduction of bacterial leaf spot severity on radish, lettuce, and tomato plants grown in compost-amended potting mixes. Reduction of bacterial leaf spot severity on radish, lettuce, and tomato plants grown in compost amended potting mixes. Food and Agriculture Organization of the United Nations, AGRIS, 27(2):186-193.

Arunyanart, P., A. Surin and S. Disthaporn. 1981. Seed discouluration disease and it's chemical control. Int. Rice. Newsl. 6(3): 14-15.

Aryantha, I. P., R. Cross and D. I. Guest. 2000. Suppression of Phytophthora cinnamomi in Potting Mixes amended with uncomposted and composted animal manures. Phytopathology, 90(7): 775-82. http://dx.doi.org/10.1094/PHYTO.2000.90.7.775 
BBS. 2016. Government of the People's Republic of Bangladesh, Bangladesh Bureau of Statistics, Agriculture Wing. Estimates of Aus, Aman and Boro Rice (Husked), 2015-2016. P. 1-6, 2-8, 1-10.

Bedi, K.S. and H.S. Gill. 1960. Losses caused by brown spot disease of rice in Punjub. Indian Phytopath. 13: 161-164.

Ben Jenana, R. K., R. Haouala and M. A. Triki. 2009. Compost, compost extract and bacterial suppressive action on Pythium aphanidermatum in tomato. Pak. J. Bot, 41(1): 315-327.

Cheuk, K. 2005. Disease suppression on greenhouse tomatoes using plant waste compost. J. Environ. Sci. Heal. B. 40: 449-461.

FAO. 2016. Food and Agriculture Organization of the United Nations. www.fao.org/worldfoodsituation/csdb/en

Floyd, C.N., R.D.B. Lefroy and E.J. D’Souza. 1988. Soil fertility and sweet potato production on volcanic ash soils in the highlands of Papua New Guinea. Field Crops Res. 19: 1-25.

Goerlach, J., S.Volrath, B.G. Knauf, G. Hengy, U. Beckhove, K.H. Kogel, M. Oostendrop, T. Stub, E.Ward, H. Kessmann and J. Ryals. 1996. Benzothiodiazole, a novel class of inducers of systemic acquired resistance, activates gene expression and disease resistance in wheat. Plant cell. 8: 629-643.

IRRI. 1980. Standard Evaluation system for rice. Internatinal Rice Testing program. Loss Banos. Phillippines. P. 7-20.

Kelley, S. 2004. Building a knowledge base for compost tea. Bio Cycle. 45(6): 32-34.

Merill, R., K. Hoberecht and J. McKeon. 1998. Organic teas from compost and Manures. Organic Farming Research Foundation. P.O. Box 440 Santa Cruz.

Miah, S.A., A.K.M. Shahjahan, M.A. Hossain and N.R. Sharma. 1985. Survey of rice disease in Bangladesh. Trop. Pest Management. 31(3): 208-213.

Nelson, E. B., and M. J. Boehm. 2002. Microbial mechanics of composted induced disease suppression. Part II. Biocycle, 43(7): 45-47.

Ngakou, A., K. Nazaire and K. Hartmut. 2012. The relative effects of compost and nonaerated compost tea in reducing disease symptoms and improving tuberization of solanum tuberosum in the field. International J. of Agriculture: Res. and Rev., 2 (4): 504-512.

Padamanabhan, S.Y. 1973. "Great Bengal Famine”. Ann. Res. Phytopath. 11: 11-24.

Pane, C., R. Spaccini, A. Piccolo, F. Scala and G. Bonanomi. 2011. Compost amendments enhance peat suppressiveness to Pythium ultimum, Rhizoctonia solani and Sclerotinia minor. Biological Control, 56(2): 115-124. http://dx.doi.org/10.1016/j.biocontrol.2010.10.002.

Papavizas, G. C. and R. D. Lumsden. 1980. Effect of microbial antagonists in the control of soil-borne root infecting fungi in tomato and okra. Pakistan J. Bot. 26(1): 179-182.

Paplomatas J. 2005. Evaluation of compost amendments for suppressiveness against Verticillium wilt of eggplant and study of mode of action using a novel Arabidopsis pathosystem. Eur J Plant Pathol. 112: 183-189. 
Percich, J.A. and C.M. Huot. 1989. Comparison of propiconazole and mancozeb applied individually or sequentially for management of fungal brown spot of wild rice. Plant Dis. 73(3): 257-259.

Preston S.R. 1990. Investigations of compost $\times$ fertilizer interactions in sweet potato grown on volcanic ash soils in the highlands of Papua New Guinea. Trop. Agric. 67: 239-242.

Rou, P.V. 2003. Suppression of tomato early blight by spraying of animal manure based compost water extracts. Suppression of tomato early blight by spraying of animal manure based compost water extracts. Annals of the Srilanka Dep. of Agric. 5: 175191.

Ryan, M., D.Wilson, P. Hepperly, J.Travis, N. Halbrendy and A. Wise. 2005. Compost tea potential is still brewing. Biocycle. 46: 30-32.

Saadi, I., Y. Laor, S. Medina, A. Krassnovsky and M. Raviv. 2010. Compost suppressiveness against Fusarium oxysporum was not reduced after one-year storage under various moisture and temperature conditions. Soil Biol Biochem, 42(4): 626634. http://dx.doi.org/10.1016/j.soilbio.2009.12.016

Salim, M., M. Akram, M. Ehsan and M. Ashraf. 2003. Rice a production handbook PARC, Pakistan.

Santos, G.R. dos., M.D. Castroneto, M. Ignacio, G.Q. Furtado, P.H.N. Rancel, L.M. Silva and F.F. Riveiro. 2009. Resistance of upland rice genotypes to rice disease at the south of Tocantins State. Bio. Sci. J. 25(6): 96 -105.

Shahjahan, A.K.M., T. Duve and J.M. Bonman. 1987. Climate and rice disease. In weather and rice. IRRI, Los Banon, Lequa, Philippines, P. 125-128.

Shaikh, A. H. and A. Ghaffar. 2004. Effect of poultry manure and sawdust on survival of sclerotia Macrophomina phaseolina in soil. Pak. J. Bot., 36(2): 425-428.

Srikumar, T.S. and P.A. Ockerman. 1990. Effect of fertilization and manuring on the content of some nutrients in potato (var. Provita). Food Chem. 37: 47-50.

Wickramaarachchi, W.A.R.T., P.N.N. Reddy, T.V. Reddy and P.V. Rao. 2003. Suppression of tomato early blight by spraying of animal manure based compost water extracts. Annals of the Sri Lanka Dep. of Agric. 5: 281-290.

Zinati, G.M. 2005. Compost in the 20th century: a tool to control plant diseases in nursery and vegetable crops. Hort. Tech. 15(1): 61-66. 
